\title{
Reproductive Rights of Married Women: A Case Study in Selangor
}

Norhana Ahad, Mohammad Fahmi Abdul Hamid, Mohd Farhan Md Ariffin, Mohd Syukri Mohd Noor, Nurul Hidayah Aziz

To Link this Article: http://dx.doi.org/10.6007/IJARBSS/v11-i12/11866

DOI:10.6007/IJARBSS/v11-i12/11866

Received: 16 October 2021, Revised: 20 November 2021, Accepted: 30 November 2021

Published Online: 12 December 2021

In-Text Citation: (Ahad et al., 2021)

To Cite this Article: Ahad, N., Hamid, M. F. A., Ariffin, M. F. M., Noor, M. S. M., \& Aziz, N. H. (2021). Reproductive Rights of Married Women: A Case Study in Selangor. International Journal of Academic Research in Business and Social Sciences, 11(12), 1166-1180.

Copyright: (C) 2021 The Author(s)

Published by Human Resource Management Academic Research Society (www.hrmars.com) This article is published under the Creative Commons Attribution (CC BY 4.0) license. Anyone may reproduce, distribute, translate and create derivative works of this article (for both commercial and non0-commercial purposes), subject to full attribution to the original publication and authors. The full terms of this license may be seen at: http://creativecommons.org/licences/by/4.0/legalcode

Vol. 11, No. 12, 2021, Pg. 1166 - 1180

Full Terms \& Conditions of access and use can be found at http://hrmars.com/index.php/pages/detail/publication-ethics 


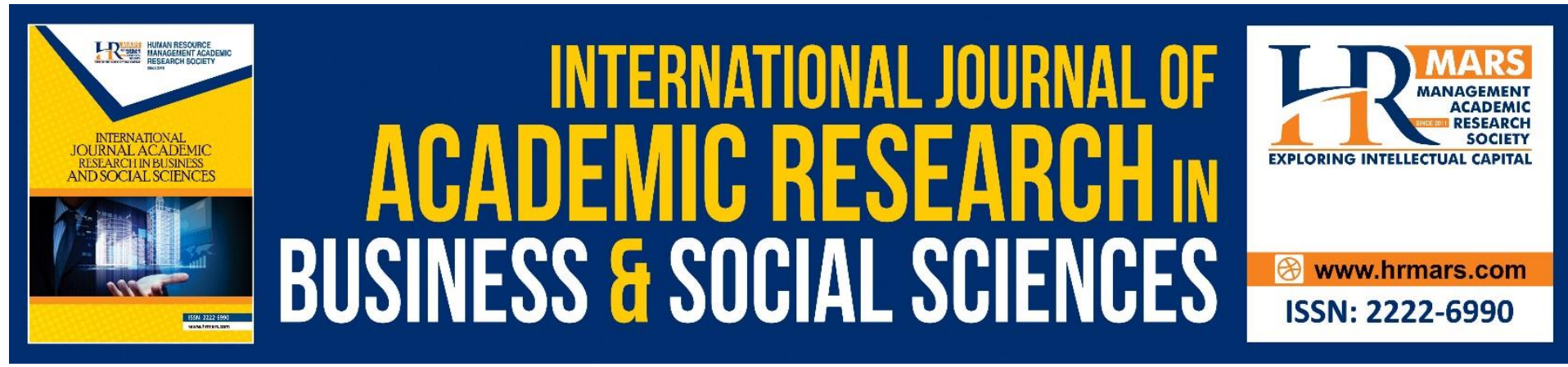

\title{
Reproductive Rights of Married Women: A Case Study in Selangor
}

\author{
Norhana Ahad ${ }^{1}$, Mohammad Fahmi Abdul Hamid², Mohd \\ Farhan Md Ariffin ${ }^{3}$, Mohd Syukri Mohd Noor ${ }^{4}$, Nurul Hidayah \\ Aziz ${ }^{5}$
}

${ }^{1}$ General Studies Department, Politeknik Melaka, 75260 Malim, Melaka, Malaysia, ${ }^{2}$ Academy of Contemporary Islamic Studies (ACIS), Universiti Teknologi MARA, Melaka Branch, Lendu

Campus, 78000 Alor Gajah, Melaka, Malaysia, ${ }^{3}$ Research Centre for Quran and Sunnah, Faculty of Islamic Studies, Universiti Kebangsaan Malaysia, 43600 UKM Bangi, Selangor, Malaysia, ${ }^{4,5}$ Academy of Contemporary Islamic Studies (ACIS), Universiti Teknologi MARA,

Perak Branch, Tapah Campus, 35400 Tapah Road, Perak, Malaysia

\begin{abstract}
Married women are often exposed to the situations of 'victims' of discrimination, which is proclaimed on the ticket of obedience to the husband. Allowing every married woman to carry out her reproductive role well without any coercion and violence is a right that should be upheld by the entire family, especially the husbands. This can be seen through their right to undergo a reproductive role such as the decision to marry without coercion from any party, healthy domestic sexuality from any pressure, discriminatory practices, violence and free family planning. This matter should not be taken lightly so that there is no neglect and discrimination when they exercise the reproductive rights role of the women themselves. So, based on the community in Selangor, including women and men, this study focuses on the differences in the practices of reproductive rights of married women. The qualitative method is thru interviews with the authorities in the respective field, and of quantitative by questionnaire distributions to 472 respondents. The main results of this study through Chi Square test and Regression Logistics Stepwise method found that only aspects of pregnancy and birth were significant with the reproductive rights of married women. This indicates that there is still a protracted polemic at the domestic level for other elements such as involuntary sexual practices, unwanted pregnancies, rejection of family planning and even the practice of domestic violence. Such a thing should not happen to protect the rights of the reproductive role of women, other than underlying the household with the organization of mu'āsharah bi al-ma'rüf, so that the rights and justice of all parties can be fulfilled. Thus, the series of polemics seen in the state of Selangor on the neglect of the reproductive rights of married women, it is appropriate to expand this study to other zones in Peninsular Malaysia to obtain a more dominant result in looking at the current practice of reproductive rights of married women in this country.
\end{abstract}

Keywords: Married Women, Woman's Rights, Reproductive Rights, Reproduction, Selangor 


\section{Introduction}

Woman in Islam, have the privilege of reproduction that includes a good quality of personal protection, healthcare and sexuality. The rights are to ensure women obtain equal treatment; neither in the family nor community. However, the topic on reproductive and sexual issues is often not visible to others as such being hindered. Hence, women are always exposed to risks confront in family relationships that complicate oneself during the reproductive age (Henri, 2016). The issue should be clear, as it involves physical, spiritual and psychological impacts on women, as well as family institutions.

Scholars believe women's rights are limited not to the discussion of marriage and wealth, yet to the reproductive choices, such as decision on marriage, sexuality, pregnancy, abortion, birth control, motherhood, family planning and contraceptive usage. This corresponds to the nature of women; beings who should be respected and defend their rights. This is because women have given their role dealing with such complex phases such as during pregnancy, birth control and child lactation (Harlina, 2009).

So, this article highlights current practices pertaining to the reproductive rights of married women in the state of Selangor, which will reveal community understanding and practices. The rights encompass of marriage determination, sexuality, family planning, pregnancy, abortion, birth control and domestic violence.

\section{Literature Reviews}

The researchers such as Juliandi (2010); Yunita (2015) draw their consensus in classifying women's reproductive rights as an important element of women's health that led to determining the scope of reproductive issues. It is not focused merely on the problems related to pregnancy and birth control, undoubtedly further to the process of family planning. Family planning basically correlates to the mortality and morbidity rate of the baby or children.

In other words, it reduces certain complications that occur due to pregnancy and birth, as is the case in some countries such as Nigeria, which high-risks complications of unwanted pregnancy, maternal mortality and unsafe abortion (Adenike, 2017). Also, other researchers agree that the issue of family planning is the main focus in women's reproductive rights, including (Mueller, 1993; Mosha, 2013; Mwenegoha, 2008; Alvarez-Nieto, 2015; Henri, 2016; Harlina, 2009; Rahayu, 2013). They argue that a good quality of reproductive healthcare is related to the professional methods of family planning which encompasses sexual attitudes of women and their couples in influencing the assent, selection and effective use of contraception.

Further, it is important to project that a good standard of woman's healthcare can be formulated as a physical and spiritual condition that is well, hygienic and, the reproductive system, functions and processes is free from any interference (Anwar \& Abdullah 2000). This is concerned with the healthcare of female reproduction organs of pre-productive age (adolescence), during productive (pregnancy and child lactation) and post productive period (menopause). The cycle can be seen in figure 1, as below: 
Figure 1: The Circle of Women's Reproductive Health and Rights

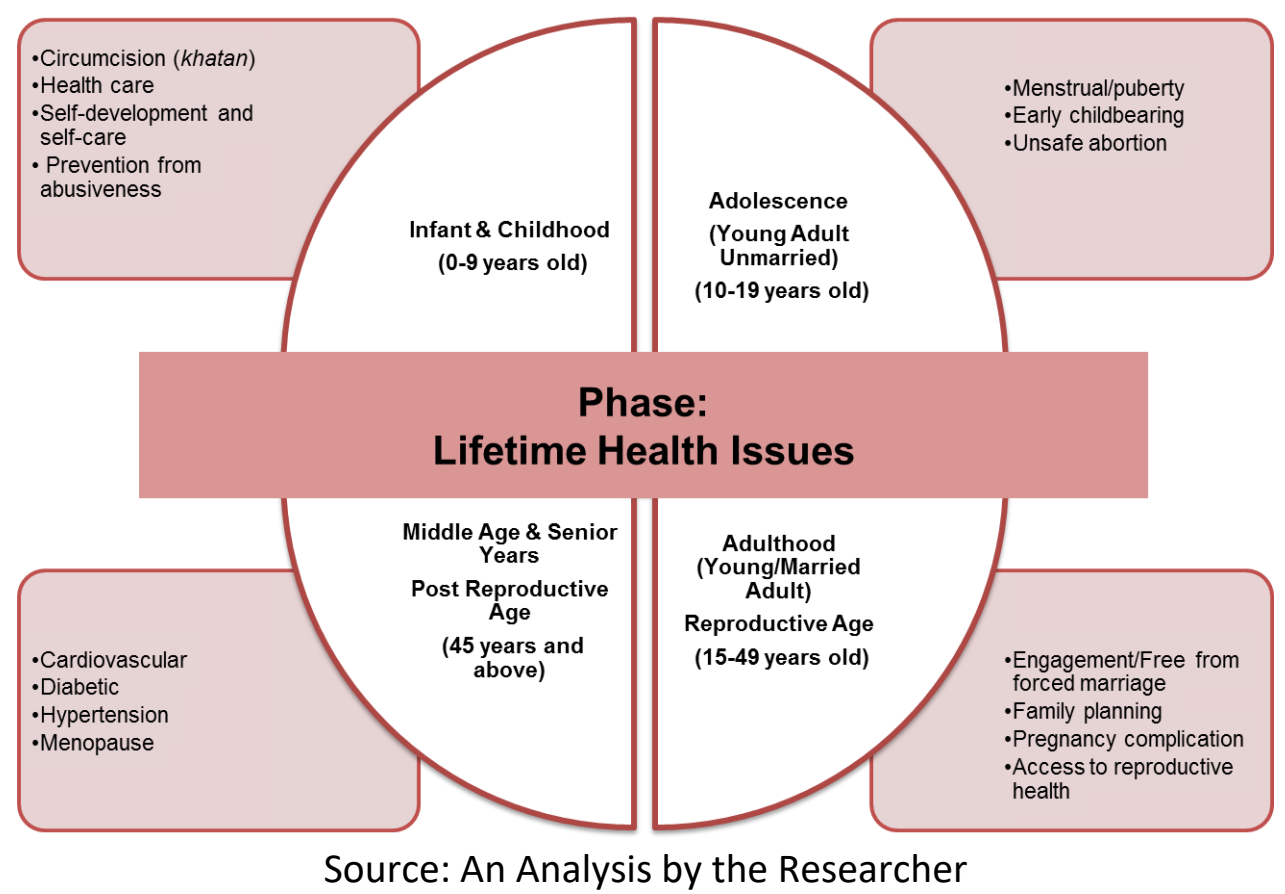

Referring to the diagram, a woman's reproductive health and rights begin at the early stage of birth till post reproductive age. It serves as a benchmark that there are reproductive needs that are encountered at every stages of life. It provides every woman indirectly, to fight for a right practice, and to avoid neglecting her reproductive rights.

Many researchers, such as Kimala (2010); Khanna (1992); Pillai (1999); Petchesky (2000); Berer (2004); Chandiramani (2005) show their concerns to woman who should achieves the highest standards in sexual and reproduction health. Meanwhile, Chrisler (2014) proposes that women are less concerned on the issue because they believes the role is limited to certain duties such as solely being a wife to husband, mother to children, household preparations compared to her self-care.

In this regard, the issue should be a basic indicator for a woman, in particular the married ones. It is to justify that their reproductive difficulties is more complex and has a greater effect than those who are not yet married. Significantly, a good and proper conduct in the form of marriage sexuality, free from coercion, the right to regulate pregnancy as well as obtaining better healthcare; highlights the women's reproductive justices in Islam.

\section{Research Methodology}

The study involves the collection of primary data through quantitative and qualitative methods. The quantitative method is carried out through the distribution of questionnaires to selected respondents in the districts of Selangor. Meanwhile, a qualitative method is used during the interview with the authoritative person in the respected fields.

The study focuses on people who live in Selangor, being married at the reproductive age that is between 20-45 as to observe their response on the issue of reproductive rights as well as their current practices. The study also marks on men in the same issue, as to identify 
the husbands' perspectives. The study was conducted in nine districts of Selangor, namely Petaling, Hulu Langat, Klang, Gombak, Kuala Langat, Sepang, Kuala Selangor, Hulu Selangor and Sabak Bernam. The hypothesis estimates regarding the reproductive health and rights of married women in Selangor will be at a satisfactory level by considering it is a state of urbanization.

Since that population is at large, the sample was performed according to the Krejchie and Morgan Table formula as well as the Cochran, so as to generalize the study on the spotted area. As a result, the study took a sample of 472 populations with a specific number of each state, to acquire an equal estimation. Next, the data collection is analyzed in order to develop a certain values; either the practice is in line to the demand of the Shari'ah or vice versa.

Additionally, the descriptive and inferential analysis also was run to examine the understanding and practices on the reproductive rights of married women. An inferential method executes to determine the relationships, connections, differences and implications that exist between one variable and another. The procedures conducted are the Chi Square Test, T Test and Logistics Regression Test. This study, thus applied inference analysis to look into a significant relationship between each variables, for instance identifying the relationship between the understanding and practices on reproductive rights of married women among the community in Selangor.

Meanwhile, the mean standard scale and its interpretation in the study is based on the model by Bernstein (1994), as the following table:

Table 1: Mean Standard Scale and Interpretation

\begin{tabular}{ll}
\hline Skor Min & Interpretasi Skor Min \\
\hline $\mathbf{1 . 0 0}-\mathbf{2 . 0 0}$ & Rendah \\
\hline $\mathbf{2 . 0 1}-\mathbf{3 . 0 0}$ & Sederhana rendah \\
\hline $\mathbf{3 . 0 1}-\mathbf{4 . 0 0}$ & Sederhana tinggi \\
\hline $\mathbf{4 . 0 1}-\mathbf{5 . 0 0}$ & Tinggi \\
\hline & Source: Nunnaly dan Bernstein (1994)
\end{tabular}

\section{Findings and Discussions}

The findings of the study engaged the overall demographic aspects of the respondents $(\mathrm{N}=$ 472 ) showed that 227 (48.1\%) male respondents and 245 (51.9\%) female respondents. The difference in numbers between the two is not very significant because a framework was implemented when the questionnaire was distributed as to ensure the offset findings. The district category of each respondent was distributed to nine districts in Selangor (Gombak, Hulu Langat, Hulu Selangor, Klang, Kuala Langat, Kuala Selangor, Petaling, Sabak Bernam and Sepang), each of which shows not a very distinctive in number (between 50 -56 people), however to confirm the results achieved in an almost fair percentage rate.

For the settlement category of urban or rural, the majority of respondents came from urban locality of 308 people (65.3\%) whereas rural neighborhoods of 164 people (34.7\%). The justification for settlement is aimed at the current practice of urban and rural communities on the issue of women's reproductive rights, whether any difference gaps or otherwise. In terms of age, the majority of the questionnaire participated by 209 people (44.3\%) by the 
ages of 31-35 years, while a total of 167 people (35.4\%) for the age group of 36 years and above. Yet, the age group of 21-30 years recorded as many as 96 people (20.4\%). All stated ages, certainly are within the reproductive age level. The respondents are also married since the study points on the reproductive contexts of married women.

In terms of educational level, the respondents' average tertiary education is within a qualification in Diploma of 242 people (51.3\%), and a Bachelor's Degree of 129 people $(27.3 \%)$. The respondents, then can be categorized as educated since the qualification level is from the Institutions of Higher Learning graduates, compared to other 100 respondents who have completed their primary school certificates (UPSR) and secondary school certificates (PMR / SPM) respectively.

Pertaining to the standard of employment, subsequently the average respondents are employee in the private sector of 246 people (52.1\%), whereas 157 people (33.3\%) in the government sectors. Between these two, the number recorded is not much different in the field of profession, either professionals or services sectors. 
The demographic summary of the respondents can be referred in table 2, as below: Table 2: Demographic

\begin{tabular}{|c|c|c|c|}
\hline No. & Demographic Variables & $N=472$ & $\%$ \\
\hline \multirow[t]{3}{*}{1} & Sex & & \\
\hline & Male & 227 & 48.1 \\
\hline & Female & 245 & 51.9 \\
\hline \multirow[t]{5}{*}{2} & Age & & \\
\hline & $21-25$ years old & 14 & 3.0 \\
\hline & $26-30$ years old & 82 & 17.4 \\
\hline & $31-35$ years old & 209 & 44.3 \\
\hline & 36 years old and above & 167 & 35.4 \\
\hline \multirow[t]{10}{*}{3} & Districts & & \\
\hline & Gombak & 50 & 10.6 \\
\hline & Hulu Langat & 54 & 11.4 \\
\hline & Hulu Selangor & 52 & 11.0 \\
\hline & Klang & 56 & 11.9 \\
\hline & Kuala Langat & 49 & 10.4 \\
\hline & Kuala Selangor & 50 & 10.6 \\
\hline & Petaling & 56 & 11.9 \\
\hline & Sabak Bernam & 51 & 10.8 \\
\hline & Sepang & 54 & 11.4 \\
\hline \multirow[t]{3}{*}{4} & Settlement Category & & \\
\hline & Urban & 308 & 65.3 \\
\hline & Rural & 164 & 34.7 \\
\hline \multirow[t]{6}{*}{5} & Education Level & & \\
\hline & Primary (UPSR) & 3 & 0.6 \\
\hline & Secondary (PMR/SPM) & 81 & 17.2 \\
\hline & Diploma & 242 & 51.3 \\
\hline & Bachelor's Degree & 129 & 27.3 \\
\hline & Others & 17 & 3.6 \\
\hline \multirow[t]{3}{*}{6} & Status & & \\
\hline & Married & 468 & 99.2 \\
\hline & Others & 6 & 0.8 \\
\hline \multirow[t]{6}{*}{7} & Employment & & \\
\hline & Self-employment & 43 & 9.1 \\
\hline & Government Service & 157 & 33.3 \\
\hline & Private Sector & 246 & 52.1 \\
\hline & Housewife & 23 & 4.9 \\
\hline & Others & 3 & 0.6 \\
\hline \multirow[t]{3}{*}{8} & Employment Level (Government) & & \\
\hline & Professional & 92 & 19.5 \\
\hline & Services & 65 & 13.8 \\
\hline \multirow[t]{3}{*}{9} & Employment Level (Private) & & \\
\hline & Professional & 91 & 19.3 \\
\hline & Services & 155 & 32.8 \\
\hline
\end{tabular}


Referring to the respondents' understanding on the reproductive subject of married women in Selangor, the results show that the overall response is moderate. The segments of pregnancy and abortion even show a high level of understanding.

As for the pregnancy, the average respondents agreed that it is a transparent life as a husband and wife. Despite showing a high understanding level of abortion, they should refine their misunderstandings relating to abortion process as permitted in Islam. This is to verify that there is no absolute assumption that abortion is a permissible practice in Islam regardless of certain standards or darar (Maria, 2006). The other domains show moderate levels which explain an inconsistent understanding of the reproductive rights of married women.

A summary of the findings can be seen in table 3 , as below:

Table 3: Respondents' Understanding on Reproductive Rights of Married Women

\begin{tabular}{llll}
\hline & Min & $\begin{array}{l}\text { Standard } \\
\text { Deviation }\end{array}$ & Scale \\
\hline Marriage & 3.10 & 0.62 & Moderate \\
Sexuality & 3.60 & 0.36 & Moderate \\
Pregnancy & $\mathbf{3 . 7 0}$ & 0.42 & High \\
Contraception & 3.23 & 0.39 & Moderate \\
Abortion & $\mathbf{4 . 1 3}$ & 0.42 & High \\
Birth Control & 3.52 & 0.57 & Moderate \\
Violence & 3.34 & 0.35 & Moderate \\
Total & $\mathbf{3 . 5 2}$ & $\mathbf{0 . 3 2}$ & Moderate \\
\hline
\end{tabular}

Source: A Questionnaire Survey of 2018

Furthermore, the practice of reproductive rights shows various feedbacks amongst the elements. The question focused at all nine districts in Selangor, then the level of practice by the respondents can be measured specific to certain districts.

As a result, there are four reproductive aspects related to married women that need a definite note, namely the sexual practice of husband and wife, pregnancy, contraceptive usage and domestic violence. The rest of the aspects are marriage, birth control and abortion show a moderate level of practice among the community throughout the state of Selangor. This can be read in table 4, as below: 
Table 4: Societal Practice on Women Reproductive Rights according to Domain and Districts

\begin{tabular}{|c|c|c|c|c|c|c|}
\hline \multirow[b]{2}{*}{ Practice } & & \multicolumn{3}{|c|}{ DISTRICTS } & & \multirow[b]{2}{*}{$\begin{array}{l}\text { Kuala } \\
\text { Langa } \\
(\mathrm{N}=49\end{array}$} \\
\hline & & $\begin{array}{l}\text { Gombak } \\
(\mathrm{N}=50)\end{array}$ & $\begin{array}{l}\text { Hulu } \\
\text { Langat } \\
(\mathrm{N}=54)\end{array}$ & $\begin{array}{l}\text { Hulu } \\
\text { Selangor } \\
(\mathrm{N}=52)\end{array}$ & $\begin{array}{l}\text { Klang } \\
(\mathrm{N}=56)\end{array}$ & \\
\hline Marriage & $\begin{array}{l}\text { Coercion-free } \\
\text { marriage }\end{array}$ & 43 & 38 & 42 & 41 & 35 \\
\hline \multirow[t]{2}{*}{ Sexuality } & $\begin{array}{l}\text { Sexually active } \\
\text { between partner }\end{array}$ & 48 & 38 & 52 & 50 & 41 \\
\hline & $\begin{array}{l}\text { Sexual conducts } \\
\text { unwilled by the } \\
\text { wife }\end{array}$ & 38 & 16 & 52 & 33 & 39 \\
\hline \multirow[t]{2}{*}{ Pregnancy } & $\begin{array}{l}\text { Unwanted } \\
\text { pregnancy }\end{array}$ & 24 & 9 & 51 & 22 & 30 \\
\hline & $\begin{array}{l}\text { Positive } \\
\text { engagement by } \\
\text { the husband on } \\
\text { the physical care } \\
\text { of the wife }\end{array}$ & 47 & 51 & 52 & 54 & 48 \\
\hline \multirow[t]{3}{*}{ Contraception } & $\begin{array}{l}\text { The ideal phase of } \\
\text { child lactation }\end{array}$ & 20 & 18 & 24 & 30 & 18 \\
\hline & $\begin{array}{l}\text { Child lactation } \\
\text { break due to } \\
\text { economic status }\end{array}$ & 40 & 42 & 24 & 48 & 41 \\
\hline & $\begin{array}{l}\text { Contraceptive } \\
\text { usage }\end{array}$ & 22 & 21 & 23 & 35 & 33 \\
\hline Abortion & $\begin{array}{l}\text { Health as main } \\
\text { issue of abortion }\end{array}$ & 3 & 4 & 0 & 0 & 1 \\
\hline Birth Control & $\begin{array}{l}\text { Positive } \\
\text { commitments } \\
\text { from partner }\end{array}$ & 44 & 48.5 & 45.5 & 50 & 45 \\
\hline \multirow[t]{2}{*}{$\begin{array}{l}\text { Domestic } \\
\text { Violence }\end{array}$} & $\begin{array}{l}\text { Situations that } \\
\text { impact insecurity } \\
\text { of the wife }\end{array}$ & 26 & 26 & 2 & 21 & 16 \\
\hline & $\begin{array}{l}\text { Husband } \\
\text { aggressiveness to } \\
\text { the wife-words } \\
\text { /actions/sexual } \\
\text { practices }\end{array}$ & 12 & 10 & 0 & 26 & 20 \\
\hline
\end{tabular}

\begin{tabular}{|c|c|c|c|c|c|}
\hline \multirow[b]{2}{*}{ Practice } & & \multicolumn{4}{|l|}{ DISTRICTS } \\
\hline & & $\begin{array}{l}\text { Kuala } \\
\text { Selangor } \\
(\mathrm{N}=50)\end{array}$ & $\begin{array}{l}\text { Petaling } \\
(\mathrm{N}=56)\end{array}$ & $\begin{array}{l}\text { Sabak } \\
\text { Bernam } \\
(\mathrm{N}=51)\end{array}$ & $\begin{array}{l}\text { Sepang } \\
(\mathrm{N}=54)\end{array}$ \\
\hline Marriage & Coercion-free marriage & 46 & 24 & 50 & 30 \\
\hline Sexuality & $\begin{array}{l}\text { Sexually active between } \\
\text { partner }\end{array}$ & 50 & 43 & 51 & 45 \\
\hline
\end{tabular}




\begin{tabular}{|c|c|c|c|c|c|}
\hline & $\begin{array}{l}\text { Sexual conducts unwilled by } \\
\text { the wife }\end{array}$ & 50 & 25 & 51 & 38 \\
\hline \multirow[t]{2}{*}{ Pregnancy } & Unwanted pregnancy & 49 & 19 & 49 & 26 \\
\hline & $\begin{array}{l}\text { Positive engagement by the } \\
\text { husband on the physical } \\
\text { care of the wife }\end{array}$ & 50 & 53 & 51 & 51 \\
\hline \multirow[t]{3}{*}{ Contraception } & $\begin{array}{l}\text { The ideal phase of child } \\
\text { lactation }\end{array}$ & 31 & 21 & 32 & 19 \\
\hline & $\begin{array}{l}\text { Child lactation break due to } \\
\text { economic status }\end{array}$ & 18 & 46 & 27 & 45 \\
\hline & Contraceptive usage & 19 & 24 & 22 & 33 \\
\hline Abortion & $\begin{array}{l}\text { Health as main issue of } \\
\text { abortion }\end{array}$ & 0 & 2 & 0 & 1 \\
\hline Birth Control & $\begin{array}{l}\text { Positive commitments from } \\
\text { partner }\end{array}$ & 48 & 49.5 & 50 & 50 \\
\hline \multirow[t]{2}{*}{$\begin{array}{l}\text { Domestic } \\
\text { Violence }\end{array}$} & $\begin{array}{l}\text { Situation that impacts } \\
\text { insecurity of the wife }\end{array}$ & 5 & 7 & 6 & 9 \\
\hline & $\begin{array}{l}\text { Husband aggressiveness to } \\
\text { wife-words/actions/sexual } \\
\text { practices }\end{array}$ & 0 & 4 & 4 & 17 \\
\hline
\end{tabular}

Source: A Questionnaire Survey of 2018

Of each stated domain, the districts of Petaling and Sepang particularly show a weak feedback on the practice of free from marital coercion.

All districts then have shown the continuity of active sexual intercourse between husband and wife. Nonetheless, the results show the wife is often forced to have sexual practices out of their wills. This sexual practice tendency is a regular form of insistences, and the wife does not favor sexual needs due to several factors of flat refusal. The districts that project the shortcomings are districts of Gombak, Hulu Selangor, Kuala Langat, Kuala Selangor, Sabak Bernam and Sepang. A sexual practice, in fact should be a preference by both parties.

There are certain situations that allow the wife to refuse sexual requests from the husband, if it is known to bring darar syarie (harm) to the wife. Zawawi (2015) concludes that the wife has the right to forgo the sexual invitation of the husband who is infected by HIV as it will possibly transmit to the wife. The situation also undergoes to wives who are not ready to have sex due to certain constraints such as health or emotional struggles (Hamidah, 2011). In addition, a high number was also identified for the districts of Hulu Selangor, Kuala Langat, Kuala Selangor and Sabak Bernam for unwanted pregnancy. With reference to the contraceptive usage, each district has figured moderate level.

In other words, respondents are preferred to exercise traditional contraception. This is driven by the stigma and assumptions by the society even without any verification from physicians of modern contraceptives usage. This statement is supported by the Contraceptive Prevalence Rate which is at a horizontal level even though the study is conducted for every 10 years, where the latest percentage is only $31.7 \%$ of various methods of modern 
contraception (Munirah, 2016). The given reason is commonly because of the husband's disapproval. Therefore, active participation from man and woman in the awareness campaigns on sexual and reproductive health is significant to further improve the standard of health and living (Ministry of Women, Family and Community Development, 2015).

Moreover, the society is embedded with the dogma and mind-set that the contraceptive usage threatens the wife, and being considered as contrary to Islamic demands. Whereas, the Shari'ah guides family planning is either by Tahdid al-Nas/ (limiting one's ability to pregnant by purpose) or Tanzim al-Nasl (child lactation phase and number and children planning) to manage family sturdiness and transparencies while raising children (Al-Bakri, 2018).

Thus, the limitations of understanding family planning practices lead to unwanted pregnancies in the areas mentioned earlier. As Islam classifies pregnancy as extreme fatigue, it is necessary for the husband to confirm the wife in a fit state by considering the number and space for another child. This suggestion purely does not demand for every husband, but rather an advice to convey that the wife does not barge into an unwanted pregnancy which is to confront other plausible detrimental complications in the future (Mansureh, 2015).

The practices indirectly prove that family planning and contraceptives usage are reproductive negligence. The problems for married women however, are not restricted to family planning and contraception. In addition, the situation is worsen when women or wives are underestimated as a sexual object for the husband, to the point of her reproductive and sexual rights being denied (Anwar \& Abdullah, 2000).

In terms of domestic violence, it is disquiet when the data portrays women's insecurities while they are with their husband. This is due to the husband's abusiveness to his wife either physically, verbally and sexually, by focusing on the districts of Gombak, Hulu Langat, Klang and Kuala Langat. Based on statistics, Selangor has recorded the highest cases of domestic violence compared to other states from 2010-2015 (Ullfah, 2016).

It can be concluded, the four topics of reproductive i.e. sexuality, pregnancy, contraceptive usage and domestic violence are the polemics binding in the community in Selangor. Others, such as the marital selection, abortion and birth control, are in a good state and coincide with the need for the social moral values. Yet, Munirah (2016) stands on her point that Selangor recorded the highest number in terms of lack of proper care of the reproductive health of married women.

In other methods, the inferential analysis highlights the Chi Square Test in order to read the relationship between the respondents' understanding and their practices. Stepwise Logistics Regression Test is also used to identify significant factors that influence respondents' understanding and practices of women's reproductive rights.

As a result, the findings show that there is a significant difference between the sexes in every aspect of the reproductive rights of married women where the value of women ahead of men, except for the abortion. These differences can be seen in table 5 , as below: 
Table 5: T Test Differences between Men and Women

\begin{tabular}{lllllll}
\hline & \multicolumn{2}{l}{ Men $(\mathrm{N}=227)$} & \multicolumn{2}{l}{ Women $(\mathrm{N}=245)$} \\
& Min & $\begin{array}{l}\text { Standard } \\
\text { Deviation }\end{array}$ & Min & $\begin{array}{l}\text { Standard } \\
\text { Deviation }\end{array}$ & $t$ & $P$ \\
\hline Marriage & 2.80 & 0.46 & 3.37 & 0.62 & -11.44 & $0.001^{*}$ \\
Sexuality & 3.44 & 0.28 & 3.76 & 0.35 & -10.70 & $0.001^{*}$ \\
Pregnancy & 3.51 & 0.35 & 3.88 & 0.40 & -10.40 & $0.001^{*}$ \\
Contraception & 3.01 & 0.31 & 3.43 & 0.35 & -13.80 & $0.001^{*}$ \\
Abortion & 4.16 & 0.35 & 4.10 & 0.48 & 1.65 & 0.100 \\
Birth Control & 3.22 & 0.51 & 3.80 & 0.48 & -12.72 & $0.001^{*}$ \\
Violence & 3.17 & 0.25 & 3.50 & 0.36 & -11.60 & $0.001^{*}$ \\
Total & $\mathbf{3 . 3 3}$ & $\mathbf{0 . 2 4}$ & $\mathbf{3 . 6 9}$ & $\mathbf{0 . 2 9}$ & $\mathbf{- 1 4 . 6 8}$ & $\mathbf{0 . 0 0 1 *}$ \\
\hline
\end{tabular}

Source: A Questionnaire Survey of 2018

The feedbacks thus show that reproductive is more synonymous to women than men. However, this is not an unconventional perception because it is an experience countered specifically by woman. Hence, it is possible for a woman to undergo the idea.

Meanwhile, the findings also show a relationship between the level of understanding and practices of the respondents in Selangor related to the reproductive rights of married women, regards to marriage, pregnancy, family planning, contraception, abortion, birth control and domestic violence. This can be seen in table 6, as below:

Table 6: Relationship of Understanding and Practices on Women's Reproductive Rights

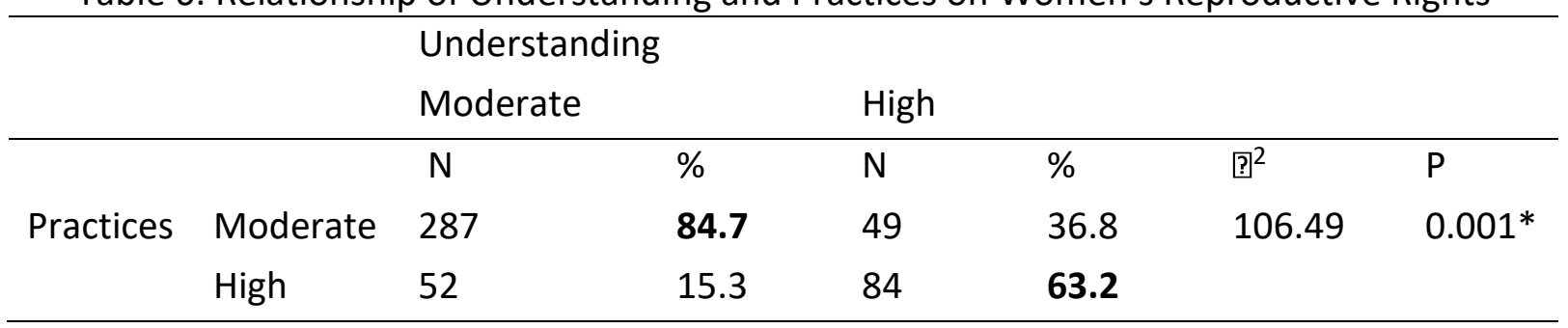

Source: A Questionnaire Survey of 2018

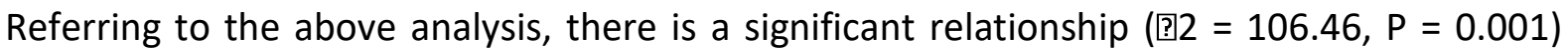
relating to reproductive understanding and practices of married women with a moderate value, which is $84.7 \%$, differ to the high reproductive understanding and practices, which is statistically $63.2 \%$. Hence, there is a moderate correlation between the understanding and practices of reproductive rights of married women. Although the findings indicate that there is a significant relationship between the two, the existing understanding in current practices is at average level. It can be deduced that the understanding and practices by the society related to reproductive rights are not at an emboldening level.

There is a demand to achieve a high level of understanding and practices correlations. The justification is that the practice is structured by the cognitive domain of an individual. To Anonuevo (1993), understanding is an internal factor that configures one's practice. The higher or greater level of understanding, then will lead to positive practices. 
In summary, the findings present that the pattern of societal practice in Selangor on the reproductive rights of married women is influenced by the level of understanding of the respondents. Further, Hilya (2016); Zarinah (2015) believe the low understanding level among the community pertaining to reproductive rights of women can affect the current practices. This creates an indicator that members of society are even oblivious to the importance of maintaining reproductive health. A rectification is required for closing the existing gaps, so that there is no serious renunciation of the reproductive rights of married women.

Furthermore, the findings from the Stepwise Logistics Regression Test show that pregnancy and childbirth have a significant influence on the reproductive rights of married women. This can be seen where the pregnancy factor affects 2.66 times in the society that plays the role of reproductive rights of married women, and shows a statistical significant effect (Wald $=9.16, P=0.001$ ). While the birth factor has an effect of 2.91 times in the community and also provides a significant effect (Wald $=18.90, P=0.001$ ). Findings can be seen as the table below:

Table 7: Significant Factors that influences Reproductive Rights of Married Women

\begin{tabular}{llllllllll}
\hline & & \multicolumn{10}{c}{$\begin{array}{l}95 \% \\
\text { EXP(B) } \\
\end{array}$} & $B$ & Wald & Sig. & Exp(B) & Cower & Upper & $\begin{array}{l}\text { Cox \& Snell } \\
\text { R2 Square }\end{array}$ & $\begin{array}{l}\text { Nagelkerke } \\
\text { R Square }\end{array}$ \\
\hline Pregnancy & 0.98 & 9.16 & 0.00 & 2.66 & 1.41 & 5.00 & 0.16 & 0.21 \\
Birth & 1.07 & 18.90 & 0.00 & 2.91 & 1.80 & 4.70 & & \\
Constant & -7.92 & 62.61 & 0.00 & 0.00 & & & & \\
\hline
\end{tabular}

Source: A Questionnaire Survey of 2018

From the descriptive table, the aforementioned factors affect or influence 21\% (Nagelkerke $\mathrm{R}$ Square $=0.21$ ) on the reproductive rights of married women. While other factors such as marriage, sexuality, family planning, abortion and domestic violence do not confess a significant impact on women's reproductive rights. Thus, it can be concluded that the reproductive rights of married women are given less attention where in the best way that they should be obtained. Accordingly, the pregnancy and birth factors are the values that persist for a woman, unfortunately, is a dogma that should be rectified.

It can be acknowledged from the analysis; there is a polemic of married women contexts, especially in the state of Selangor. Among the main discussions is that married women are given little space in carrying out other reproductive roles such as marriage selection, befitting pregnancy phase and maternal care (Noriza, 2017). As married women carried the reproductive rights much more complicated than the unmarried, it can certainly lead to some indirect denial and ignorance.

The role of married women should take into account as produces a great impact due to their capability of managing the wholeness of family institution. The visible analysis proves that despite the advanced feminism fights in Malaysia and Southeast Asia, there are still gaps in the context of understanding, care and practices in the reproductive aspects of women, especially for married women (Rahayu, 2013). 
In conclusion, the efforts to recognize women's reproductive rights as one of the human rights instruments is to seek that woman are given equal opportunities to make decisions in determining their interests. If it fails to be observed, bad implications are triggered to women and family institutions. This initiative will not be successful if there is no mutual cooperation from the couple. In fact, awareness campaigns need to be intensified as much as possible in society, so that the denial of women's reproductive rights can be reduced. At the family level, the principle of justice mainly for woman must be an utmost agenda to truly be strengthened, and not acts just as a silent submissive patriarchy.

\section{Corresponding Author}

Mohd Farhan Bin Md Ariffin

Research Centre for Quran and Sunnah, Faculty of Islamic Studies, Universiti Kebangsaan Malaysia, 43600 UKM Bangi, Selangor, Malaysia

Email: farhan.ariffin@ukm.edu.my

\section{References}

Medel-Anonuevo, C., Namtip, A., Unesco Institute for Education., \& International Seminar on Women's Education and Empowerment. (1995). Women, Education And Empowerment: Pathways Towards Autonomy : Report Of The International Seminar Held At UIE, Hamburg, 27 January-2 February 1993. Hamburg, Germany: UNESCO Institute for Education. Melalui https://unesdoc.unesco.org/ark:/48223/pf0000100662

Carmen, A. N. (2015). Sexual and reproductive health beliefs and practices of female immigrants in Spain: A Qualitative Study. Reproductive Health Journal. 12(79). 1-10

Chandiramani, R. (2005). Mapping the Contours: Reproductive Health and Rights and Sexual Health and Rights in India. In W. Chavkin \& E. Chesler (Ed.), Where Human Rights Begin: Health, Sexuality and Women in the New Millenium. (pp. 127-153). Ithaca, NY: Rutgers University Press. https://doi.org/10.36019/9780813541181-007

Mwenegoha, H. O. (2008). Women's Reproductive Rights and Autonomy Under Islam as They Intersect with Human Rights Entitlements and Customary Norms and Practices in Tanzania: Lushoto as a Case Study. (Master Thesis) Faculty of Law, University of Zimbabwe. 36.

Siraj, H. H. (2009). Citra Wanita Kontemporari. Kuala Lumpur: JIMedia. 26, 66, 35, 53.

Shalahudin, H. (2016). Wacana Kesetaraan Gender dalam Pemikiran Islam di Institusi Pengajian Tinggi Islam Negeri Di Indonesia: Kajian Kes Di Universitas Islam Negeri Sunan Kalijaga Yogyakarta. (Ph.D Thesis) Akademi Pengajian Islam, Universiti Malaya. 332.

Khanna, J., Look, P., \& Griffin, P.D. (1992). Reproductive health : a key to a brighter future : biennial report 1990-1991 : special 20th anniversary issue. Studies in Family Planning, 24, 267.

Ahmad, J. (2002) Pemupukan Budaya Penyelidikan Dikalangan Guru di Sekolah: Satu Penilaian. (Ph.D. Thesis) Fakulti Pendidikan Universiti, Kebangsaan Malaysia, Bangi.

Chrisler, J. C. (2014). A Reproductive Justice Approach to Women's Health. Analyses of Social Issues and Public Policy, 14, 205-209.

Harahap, J. (2010). Panduan Pendidikan Hak \& Kesehatan Reproduksi. Jakarta: Rahima. 22. Kementerian Pembangunan Wanita, Keluarga dan Masyarakat. N.d. Kajian Nasional Hak Reproduktif dan Kesihatan Seksual Wanita. Dicapai pada 25 September 2015, 
http://portal.kpwkm.gov.my/documents/10156/8c4b885c-d644-43fa-9f054bf27cbb031a.

Yazdkhasti, M., Pourreza, A., Pirak, A., \& Abdi, F. (2015). Unintended Pregnancy and Its Adverse Social and Economic Consequences on Health System: A Narrative Review Article. Iranian Journal of Public Health, 44(1), 12-21.

Berer M. (2004). Sexuality, Rights and Social Justice. Reproductive Health Matters, 12(23), 611. https://doi.org/10.1016/s0968-8080(04)23130-5

Anshor, M. U. (2015). Fikih Aborsi Wacana Penguatan Hak Reproduksi Perempuan. Jakarta: Penerbit Buku Kompas. 38-39.

Bakar, M. Z., Zain, R. M., \& Abdullah, W. N. (2015). Kewajipan Isteri Menunaikan Nafkah Batin Kepada Suami Yang Dijangkiti HIV/AIDS: Kajian Menurut Undang-Undang Keluarga Islam Dan Kajian Kes.

Mosha, I., Ruben, R., \& Kakoko, D. (2013). Family Planning Decisions, Perceptions And Gender Dynamics Among Couples In Mwanza, Tanzania: A Qualitative Study. BMC Public Health, 13, 523. https://doi.org/10.1186/1471-2458-13-523

Esiet, O. A. (2017). Adolescent Sexual and Reproductive Health in Nigeria. In Action Health Incorporated.Melaluihttps://www.wilsoncenter.org/sites/default/files/media/docum ents/event/Esiet\%20Presentation.pdf . 18.

Pillai, V. K., \& Wang, G. S. (1999). Women's Reproductive Rights in Developing Countries. England: Ashgate Publishing Company. 10.

Price, K. (2010). What Is Reproductive Justice?: How Women Of Color Activists Are Redefining The Pro-Choice Paradigm. In Meridians, 10(2), 42-65. https://doi.org/10.2979/meridians.2010.10.2.42

Petchesky, R. P. (2000). Reproductive and Sexual Rights: Charting the Course of Transnational Women's NGOs. New York: United Nations Research Institute for Social Development. 9

Ariffin, R. N. R., Talib, M. A., Satar, N., Othman, A., Hanafi, H., Tumin, M., \& Zahari, R. K. (2017). Muslim Women's Sexual and Reproductive Health Rights: Evidence from the United States, Iran and Malaysia. In Journal of Business and Social Development. (5)2. 1-8

Dixon-Mueller, R. (1993). The Sexuality Connection in Reproductive Health. Studies in Family Planning, 24(5), 269-282. https://doi.org/10.2307/2939221

Sahib, S. Z. (2015). Kurang Pengetahuan Kaedah Kontraseptif. In Harian Metro, 31 Ogos 2015. Dicapai pada 10 Mei 2017 melalui https://www.hmetro.com.my/node/74064

Sanusi, S. R. (2013). Kesihatan Reproduktif dalam Kalangan Wanita Miskin Bandar di Bandar Medan Sumatera Indonesia. (Ph.D Thesis) Jabatan Antropologi dan Sosiologi, Fakulti Sastera dan Sains Sosial, Universiti Malaya, Kuala Lumpur. 13, 35.

Hamidah, T. (2011). Fiqh Perempuan Berwawasan Keadilan Gender. Indonesia: UIN Maliki Press. 110.

Masita, Y. M. (2015). Hak Reproduksi Pengaturan Jumlah Anak dan Pemilihan Alat Kontrasepsi. (Master Thesis) Program Pascasarjana Prodi Ilmu Kesehatan Masyarakat Universitas Sebelas Maret Surakarta. Indonesia. 8

Anwar, Z., \& Abdullah, R. (2000). Reproductive Health and Rights: The Importance for Muslim Women. Kuala Lumpur: Sister In Islam. 20, 22, 26-27.

Bakri, Z. (2017). Hukum Perancangan Keluarga. In al-Kafili al-Fatawi, dicapai pada 13 Disember 2017, http://www.muftiwp.gov.my/index.php/ms-my/perkhidmatan/alkafili-al-fatawi/574-hukum-perancagan-keluarga 